\title{
The effect of gap size on growth and species composition of 15-year-old regrowth in mixed blackbutt forests
}

\author{
Matthew Kinny ${ }^{1,2,3}$, Chris McElhinny ${ }^{1}$ and Geoff Smith ${ }^{4}$ \\ ${ }^{1}$ Australian National University, College of Sciences, The Fenner School of Environment and Society, \\ Forestry Building 48, Linnaeus Way, Canberra ACT 0200, Australia \\ ${ }^{2}$ Current address: Forests NSW, Private Bag 9004, Grafton, NSW 2460, Australia \\ 3Email: matthew.kinny@sf.nsw.gov.au \\ ${ }^{4}$ Forests NSW, PO Box J19, Coffs Harbour Jetty, NSW 2450, Australia
}

Revised manuscript received 31 January 2011

\section{Summary}

In north-eastern New South Wales (NSW) the Regional Forest Agreement process has transferred more than 400000 ha of state forests to national park, and restricted silviculture to 'single tree selection' and a light form of 'Australian group selection'. While these silvicultural systems are theoretically well suited to ecologically sustainable forest management, there is concern that in their current form they are not achieving adequate regeneration or optimising the growth of that regeneration. This is of particular concern for mixed-species blackbutt forest, for which there is no quantitative research concerning the growth and composition of regeneration within group-selection gaps. We address this issue by: (1) quantifying the effect of gap size, and other gap characteristics including distance from gap edge, on the growth of regeneration; and (2) assessing the effect of gap size on the composition of regeneration. We use the answers to these questions to recommend a gap size for group selection silviculture in mixed-species blackbutt forests in north-eastern NSW. We measured attributes describing the growth and composition of regeneration in nine circular group-selection gaps in mixedspecies blackbutt forest near Coffs Harbour and Wauchope. These gaps contained 14.5-15.5-y-old regeneration and provided three replicates of small (0.27-0.3 ha), medium (0.45-0.67 ha) and large (0.93-0.97 ha) gaps. ANOVA testing indicated significantly $(P<0.05)$ lower height, diameter and volume growth of dominant blackbutt stems up to five metres from gap edge. Outside this zone growth remained fairly constant, indicating dominant blackbutt trees were susceptible to suppression only in close proximity to gap edges. Multiple regression analysis confirmed the relatively short distance from gap edges over which suppression occurred, with distance to closest gap edge explaining a small proportion of the variation in the models fitted for tree- and plot-level growth. The origin of blackbutt regeneration within gaps was a significant effect in tree-level growth models, with planted stems having increased diameter and volume growth compared with stems regenerated from natural seedfall. Gap size had no significant effect on the composition of regeneration. We conclude that for the range of gaps tested, 1-ha gaps are optimal for growth because they minimise the proportion of gap within $5 \mathrm{~m}$ of the retained forest edge, without altering composition. Larger gaps have also been shown to have operational and economic benefits compared with smaller gaps.

Keywords: silviculture; regeneration; growth; models; composition; selection forest; group selection; mixed forests; Eucalyptus pilularis

\section{Introduction}

Blackbutt (Eucalyptus pilularis Smith) has a discontinuous distribution extending $1700 \mathrm{~km}$ along the eastern coast of Australia from Bega in southern NSW to Fraser Island in southern Queensland (Boland et al. 2006). Despite its widespread distribution, blackbutt dominates the composition of extensive forests only between the towns of Taree and Woolgoolga in north-eastern NSW (Floyd 1962). In this region the productivity of blackbutt forest has in the past made it the most important commercial native forest type in NSW (Baur 1983), constituting 9.5\% of the productive native forest in NSW yet contributing about $15 \%$ of native hardwood timber production (Horne et al. 1991). The widespread occurrence of blackbutt forest along the coastal plain of north-eastern NSW facilitated access and utilisation at the time of European settlement and has since resulted in its extensive modification through a variety of silvicultural systems (e.g. single-tree selection, group selection) and treatments (e.g. timber stand improvement) (Florence 1996). This history of utilisation has produced large tracts of even and uneven-aged forest, with parts of the estate now approaching maturity. The harvesting and regeneration of this mature component requires appropriate silviculture to ensure vigorous regrowth is created that will become harvestable, productive forest in the future.

The regeneration of blackbutt forest is complicated because a large proportion exists as mixed-species forest (Forestry Commission of NSW 1989). These mixed forests require blackbutt, which is intolerant of competition (Florence 1996), to be managed in association with other more tolerant species. This situation is exacerbated by most associated species maintaining a pool of lignotubers ready to respond to a disturbance in the forest canopy, whereas blackbutt does not develop lignotubers although it can develop a carrot-like swelling near the root-stem junction that appears to act as a food storage organ for young seedlings 
(Curtin and King 1979). The creation of gaps of adequate size through group-selection silviculture may therefore be crucial for the regeneration and growth of the blackbutt component in mixed-species blackbutt forest (Jacobs 1955; Baur 1983; Florence 1996).

Group selection silviculture involves the removal of groups of trees to create gaps with an environment conducive to the regeneration and growth of a new cohort of trees (Smith et al. 1996; Lamson and Leak 2000). The system endeavours to mimic small-scale natural disturbances, such as those caused by insect attack, disease or meteorological events, and is particularly suited to the regeneration of forests containing a mix of tolerant and intolerant species, leading to uneven-aged forests (Smith et al. 1996; McCarthy 2001). The individual groups may be regarded as mini-clearfells, although they are not managed as individual stands, but as components of a single larger stand (Smith et al. 1996; Lamson and Leak 2000). In Australia the system has been traditionally called ‘Australian Group Selection’ (AGS) and was applied with the objective of removing groups of commercially mature trees to create gaps conducive to the establishment and growth of regeneration, without unnecessarily sacrificing immature growing stock (Jacobs 1955; Florence 1996). This is achieved by arranging the individual groups to maximise the removal of mature trees while retaining growing stock in the matrix surrounding the gaps. The system therefore has the potential to efficiently utilise the growing stock within complex mixed-species uneven-aged forest, and also to convert even-aged forest, over time, into a more complex uneven-aged structure (Jurskis 2000).

There is no strict definition of the maximum size for a group selection gap (Bradshaw 1992). For example, Smith et al. (1996) suggested a maximum gap diameter of twice the height of a mature stand, because beyond this size the environment at the centre of the gap will be similar to that within a larger clearfell. Others have based their definition on the distance of seed dispersal from trees at the edge of the gap (Hawley 1949), or simply defined an upper area limit (Fairbairn 1963; Ovington and Thistlethwaite 1976). In practice the determination of an appropriate group-selection gap size involves a range of factors. These include the forest's ecology (e.g. relative tolerance of the primary species), site factors (e.g. stocking and condition of trees surrounding a gap), management objectives (e.g. primacy of timber production), economic factors (e.g. cost of harvesting operations), environmental impacts (e.g. effect on wildlife) and social considerations (e.g. visual impacts) (Bradshaw 1992; Florence 1996).

The current application of AGS silviculture in the north-eastern region of NSW is specified in the 'Integrated Forestry Operations Approval' under the NSW Upper and Lower North East Regional Forest Agreements (NSW Government 1999a,b). Under these guidelines groups of trees are harvested to create gaps no larger than 0.25 ha. A receptive seedbed is created by the disturbance of soil during harvesting and the burning of logging slash after harvesting. Regeneration is through natural seedfall from trees surrounding the gap, from lignotubers present at the time of harvesting, and enrichment plantings of blackbutt seedlings. At any one harvest the total area of gaps must not exceed $22.5 \%$ of the net harvestable area of the stand or tract of forest in question. The distance between gaps must be at least the average diameter of the gaps created. Following the first application of AGS no other form of harvesting is permitted until three successive AGS harvests have been completed. The minimum return time between AGS harvests is $5 \mathrm{y}$, with an average return time of at least $7 \mathrm{y}$ over the four AGS harvests. At this point $90 \%$ of the net harvestable area will have been treated. The remaining $10 \%$ of untreated harvestable forest is retained as a matrix of unlogged forest surrounding the regenerated gaps to increase structural complexity and provide mature trees for wildlife habitat.

There have been long-standing concerns regarding the size of gaps used to regenerate blackbutt forest under the AGS system (Forestry Commission of NSW 1982; Baur 1983; Horne 1993), with a range of different gap sizes advocated (Table 1). Most of these recommendations, however, are not supported by quantitative research, and gap size was identified by Baur (1983) and Horne (1993) as requiring further investigation. This work is of considerable urgency given the current restriction of blackbutt 'group selection' silviculture to the smallest prescribed gap size of any region in Australia (Table 2), coupled with a substantial decrease in the area of blackbutt forest available for timber production following the transfer of over 400000 ha of state forests to national park in the North East Regional Forest Agreement ${ }^{1}$. It is therefore critical that silvicultural practices are implemented that will ensure the optimal regeneration and growth of the remaining blackbutt estate (Horne 1993).

In this study we address the issue of gap size in blackbutt forest managed with group selection silviculture by:

- quantifying the effect of gap size and other gap characteristics on the growth of regeneration

- assessing the effect of gap size on the composition of regeneration.

We use answers to these questions to recommend a gap size for group-selection silviculture in blackbutt type forests in NE NSW.

${ }^{1}$ This excludes 283000 ha transferred before and after the Regional Forest Agreement (Auditor General 2009)

Table 1. Group selection gap sizes that have been recommended for blackbutt type forest in north-eastern New South Wales

\begin{tabular}{lcc}
\hline \multirow{2}{*}{ Source } & \multicolumn{2}{c}{ Recommended gap size } \\
\cline { 2 - 3 } & $\begin{array}{c}\text { Area } \\
(\mathrm{ha})\end{array}$ & $\begin{array}{c}\text { Diameter } \\
(\mathrm{m})^{\mathrm{A}}\end{array}$ \\
\hline DECC (2008) & 0.50 & 80 \\
NSW Government (1999a,b) & 0.25 & 56 \\
Horne (1993) & 0.32 & 64 \\
Baur (1983) & 0.15 & 44 \\
Forestry Commission of NSW (1982) & 1.0 & 113 \\
Floyd (1962) $^{\mathrm{B}}$ & 0.1 & 37 \\
Jacobs (1955) & 0.50 & 80 \\
\hline
\end{tabular}

${ }^{\mathrm{A}}$ Assumes a circular gap size

${ }^{\mathrm{B}}$ Assumes a stand height of $40 \mathrm{~m}$ 
Table 2. Comparison of the maximum gap size permitted in a range of Regional Forest Agreement regions

\begin{tabular}{|c|c|c|}
\hline RFA Region & Maximum gap size & Source \\
\hline North-eastern NSW & 0.25 ha (group selection) ${ }^{\mathrm{A}}$ & NSW Government (1999a,b) \\
\hline Southern NSW-South Coast Subregion & 0.79 ha (group selection) ${ }^{\mathrm{AB}}$ & NSW Government (2002) \\
\hline Southern NSW—-Tumut Subregion & 0.5 ha $\left(\right.$ group selection) ${ }^{\mathrm{A}}$ & NSW Government (2002) \\
\hline Tasmania & 100 ha (clearfell) ${ }^{\mathrm{C}}$ & Forest Practices Board (2000) \\
\hline Victoria (multiple regions) & 40 ha $(\text { clearfell })^{\mathrm{C}}$ & DSE (2007) \\
\hline Western Australia_-jarrah forest & 10 ha (group selection) ${ }^{\mathrm{D}}$ & CALM (2004) \\
\hline Western Australia_-karri forest & 40 ha (clearfell) & CALM (2005) \\
\hline
\end{tabular}

\footnotetext{
${ }^{\mathrm{A}}$ In a single harvest, group selection gaps may total 22.5\% of net harvestable area. For a 40-ha stand this equates to 9 ha.

${ }^{\mathrm{B}} \mathrm{A}$ gap of this size is termed 'Australian group selection heavy' and is restricted to designated areas. Outside these areas the maximum 'Australian group selection' size is 0.39 ha.

${ }^{\mathrm{C}}$ The requirement to establish a safe burning boundary may over-ride this limit.

${ }^{\mathrm{D}} \mathrm{A}$ gap size of 10 ha is restricted to designated areas. Outside these areas the maximum gap size varies between 1 ha and 0.5 ha.
}

\section{Methods}

\section{Study sites}

Potential study sites were selected from eighteen groupselection gaps established by Forests NSW between 1993 and 1994, with nine gaps located near Coffs Harbour (Wedding Bells and Orara East State Forests) and another nine near Wauchope (Burrawan State Forest) in NE NSW (Fig. 1). Bruskin (1996) details the establishment and initial monitoring of regeneration in the gaps. Each set of nine gaps comprised three replicates of small ( $0.3 \mathrm{ha}$ ), medium (0.5 ha) and large (1.0 ha) gaps of circular shape. These sizes were originally chosen to represent the range of feasible gap sizes for blackbutt forest based on predicted tree growth and the maximum size of gap that was socially acceptable (Bruskin 1996), although the smallest gap size tested was slightly larger than the maximum size currently permitted in NE NSW (0.25 ha).

A field inspection indicated that half of the gaps were unsuitable for reasons including:

- a highly elliptical shape

- actual gap size differed substantially from the planned gap size

- a location close to major roads, which reduced forest cover at the edge of gaps

- damage to regeneration during recent harvesting and roading operations.

The remaining nine gaps (three in Coffs Harbour and six in Wauchope) were suitable for use in the present study. These gaps represented three replicates of small (0.27-0.3 ha), medium (0.45-0.67 ha) and large (0.93-0.97 ha) gaps (Table 3).

Data describing the composition, basal area, height and diameter distribution of the forests surrounding the research gaps were derived from nearby permanent growth plots for the Coffs Harbour gaps, and by conducting basal area sweeps and diameter and height measurements in the forest surrounding the gaps at Wauchope. The forests were typical of mixed-species blackbutt forest in NE NSW (see Forestry Commission 1989), with a relatively complex composition made up of a mixture of species of different tolerances. For clarity, the composition of the forests in this study

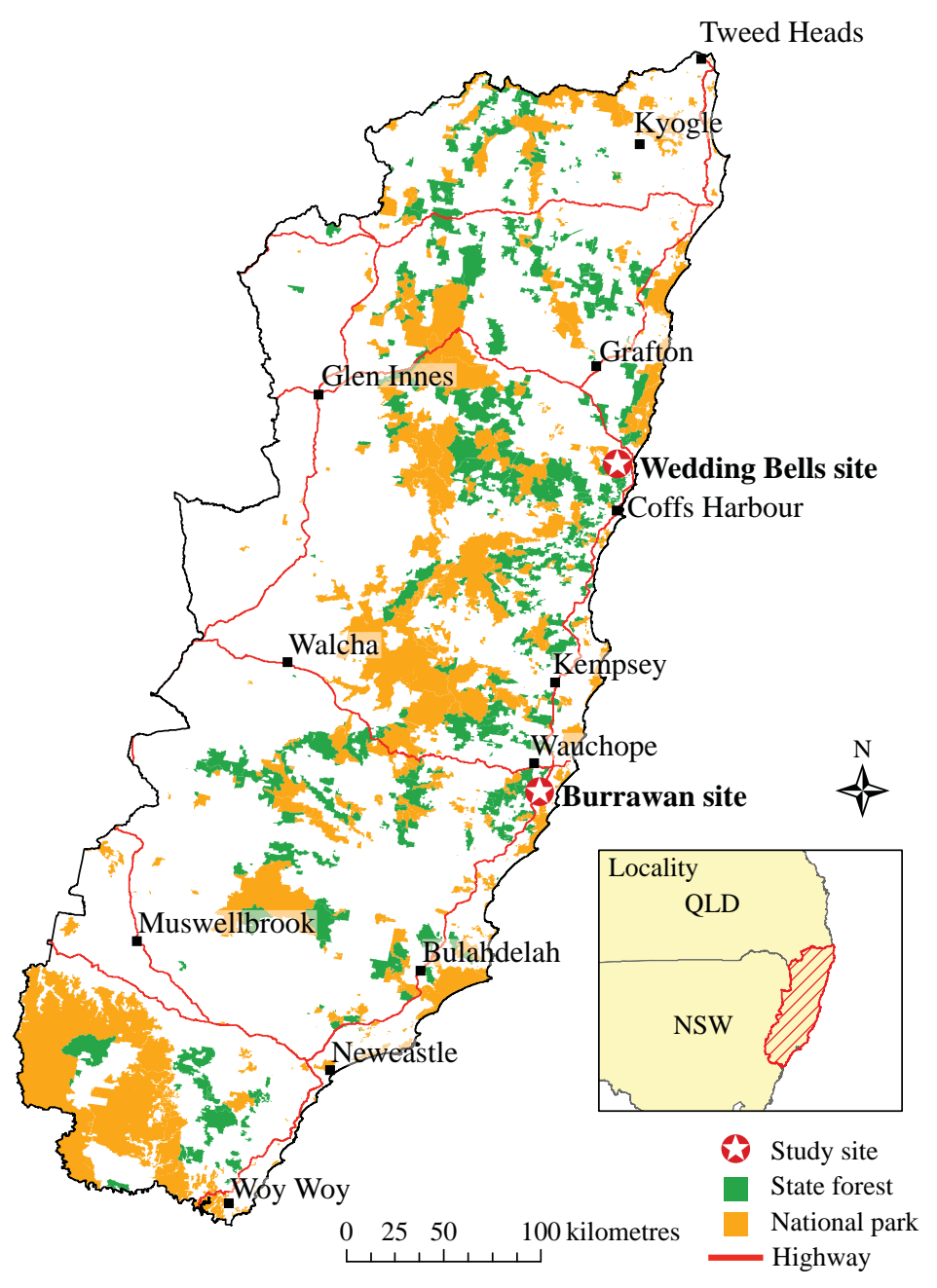

Figure 1. The nine gaps were located in two research sites near Coffs Harbour and Wauchope in north-eastern NSW

was described by grouping species as intolerant, intermediate or tolerant to competition for light (Table 4). This classification confirmed the forest surrounding the gaps at both locations was similar in terms of mean basal area and the proportion of basal area attributable to intolerant, intermediate and tolerant species (Fig. 2). The forests surrounding the gaps at Coffs Harbour and Wauchope were also similar in terms of predominant stand height (Coffs Harbour 40 m, Wauchope $43 \mathrm{~m}$ ), diameter distribution and the contribution of blackbutt to the diameter distribution (Fig. 3). 
Table 3. Size, location and stocking of nine gaps selected for the study. Gaps were established between 1993 and 1994 in mixed-species dry blackbutt type forest near Coffs Harbour and Wauchope in NE NSW

\begin{tabular}{lccccccc}
\hline District & $\begin{array}{c}\text { Size } \\
(\mathrm{ha})\end{array}$ & $\begin{array}{c}\text { Dimensions (m) } \\
(\mathrm{N}-\mathrm{S} / \mathrm{E}-\mathrm{W})\end{array}$ & $\begin{array}{c}\text { 1998 Stocking } \\
\left(\text { stems ha }^{-1}\right)\end{array}$ & Easting/northing & $\begin{array}{c}\text { Slope } \\
\left(^{\circ}\right)\end{array}$ & Aspect & Soil landscape \\
\hline Wauchope & 0.27 & $56.5 / 60.0$ & 1030 & $0475278 / 6507331$ & $2-3$ & SW & Burrawan \\
Wauchope & 0.28 & $60.0 / 60.0$ & 1400 & $0474484 / 6507612$ & $0-1$ & W & Burrawan \\
Coffs Harbour & 0.30 & $60.2 / 63.8$ & 3065 & $0514020 / 6660347$ & 0 & Flat & Ulong \\
Wauchope & 0.45 & $80.0 / 72.0$ & 1579 & $0474504 / 6507577$ & $3-5$ & SW & Burrawan \\
Wauchope & 0.47 & $79.0 / 76.3$ & 1632 & $0475258 / 6507510$ & $0-2$ & NE & Burrawan \\
Coffs Harbour & 0.67 & $89.3 / 95.0$ & 4894 & $0511741 / 6662547$ & $0-4$ & SW & Ulong \\
Coffs Harbour & 0.93 & $97.5 / 121.8$ & 2289 & $0511746 / 6657328$ & $3-5$ & W & Ulong \\
Wauchope & 0.94 & $107.7 / 111.2$ & 2047 & $0474833 / 6506984$ & $0-1$ & NE & Burrawan \\
Wauchope & 0.97 & $115.6 / 106.5$ & 1594 & $0474503 / 6507686$ & $0-1$ & W & Burrawan \\
\hline
\end{tabular}

Table 4. Common overstorey species within mixed-species blackbutt forest, classified as intolerant, intermediate or tolerant on the basis of their shade tolerance

\begin{tabular}{|c|c|}
\hline Tolerance & Species \\
\hline Intolerant & $\begin{array}{l}\text { Blackbutt-Eucalyptus pilularis Smith } \\
\text { Flooded gum-Eucalyptus grandis W.Hill ex Maiden } \\
\text { Wattle-various Acacia species }\end{array}$ \\
\hline Intermediate & $\begin{array}{l}\text { Grey gum_Eucalyptus punctata D.C. } \\
\text { Ironbark-Eucalyptus paniculata Smith } \\
\text { Pink bloodwood-Corymbia intermedia (R.T.Baker) K.D.Hill \& L.A.S.Johnson } \\
\text { Red mahogany_Eucalyptus resinifera Smith } \\
\text { Smoothbarked apple-Angophora costata (Gaertner) Britten } \\
\text { Tallowwood_Eucalyptus microcorys F.Muell. } \\
\text { White mahogany-Eucalyptus acmenoides Schauer } \\
\text { Yellow stringybark—Eucalyptus muelleriana A.Howitt }\end{array}$ \\
\hline Tolerant & $\begin{array}{l}\text { Brush box_Lophostemon confertus (R.Br.) Peter G.Wilson \& J.T.Waterh. } \\
\text { Coastal banksia_Banksia integrifolia L.f. } \\
\text { Forest oak-Allocasuarina torulosa (Aiton) L.A.S.Johnson } \\
\text { Turpentine_-Syncarpia glomulifera (Sm.) Nied. } \\
\text { Scrubwood_-various rainforest species }\end{array}$ \\
\hline
\end{tabular}

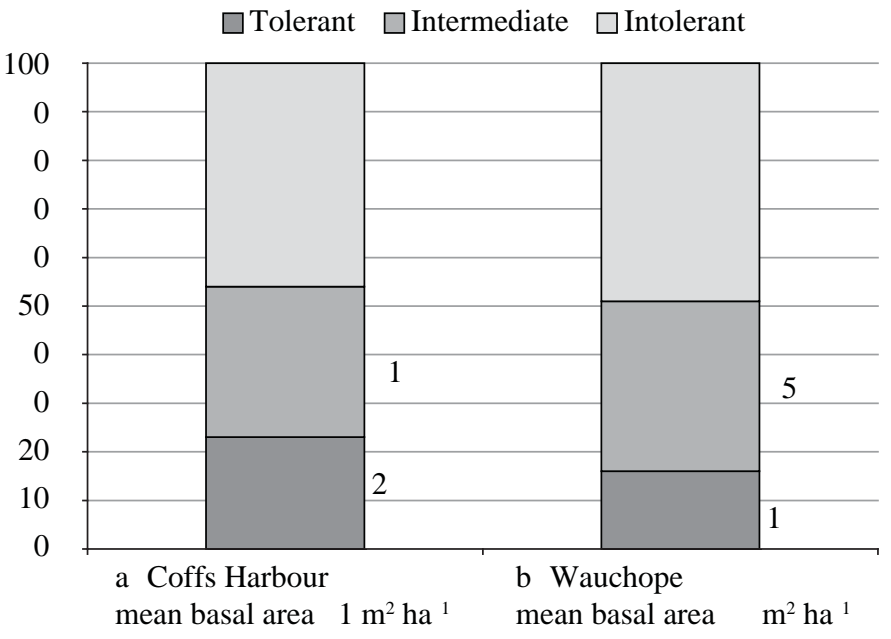

Figure 2. Forest composition surrounding research gaps at (a) Coffs Harbour and (b) Wauchope

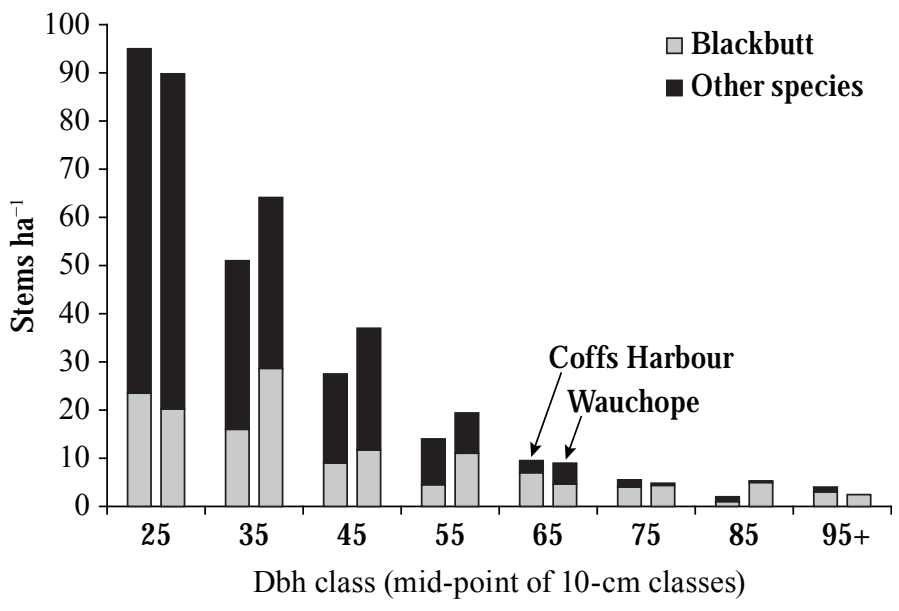

Figure 3. Diameter distribution of the forest surrounding research gaps at Coffs Harbour (left) and Wauchope (right). 
Site preparation of the selected gaps involved either windrow or broadcast burning of logging slash. This had the potential to confound the study because nutrient inputs, soil chemistry and physical properties are likely to differ depending on whether regeneration established in a windrow, in burnt logging slash or on bare soil (Chambers and Attiwill 1994). Bruskin (1996), however, found seedbed preparation had little effect on the establishment and early growth of regeneration within the research gaps. As a precaution, sampling avoided windrows or burnt logging slash, so all measurements were of regeneration on soil-disturbed seedbeds. Following site preparation, all gaps were enriched with nurserypropagated blackbutt seedlings at an average of 500 stems ha ${ }^{-1}$ to supplement natural regeneration.

\section{Sampling design and data collection}

Transects were used to sample gaps in north-south and east-west directions with small deviations $\left( \pm 5^{\circ}\right)$ to avoid burnt windrows and logging slash. Contiguous $5 \mathrm{~m} \times 5 \mathrm{~m}$ plots were located along these transect lines. Plots of this size were small enough to allow distance from gap edge to be modelled, yet large enough to sample an average of five trees per plot, with one of these having potential for selection as a final crop tree (Fig. 4). Gap edge was defined by the outermost edge of the tree crowns in the forest surrounding the gap. Transects and $5 \mathrm{~m} \times 5 \mathrm{~m}$ plots were initially set out in 1998 to record the location, origin and early growth of regeneration (Forests NSW unpublished data). To ensure initial gap regeneration was sampled, only trees that were $>1.3 \mathrm{~m}$ in height in 1998 were remeasured in the current study. Three categories were used to classify the origin of regeneration as:

1. Natural regeneration, originating from seedfall from trees at the edge of gaps, or from lignotubers established before the gaps were harvested

2. Coppice regeneration, originating from basal tissue on the stumps of harvested trees in the gaps

3. Planted regeneration, originating from tubestock seedlings planted when the gaps were established.

Between March and May 2007, transects and plots were re-established and twelve attributes describing the growth and composition of regeneration were measured within each $5 \mathrm{~m} \times 5 \mathrm{~m}$ plot (Table 5), along with a range of potential explanatory variables for modelling these 12 attributes (Table 6).

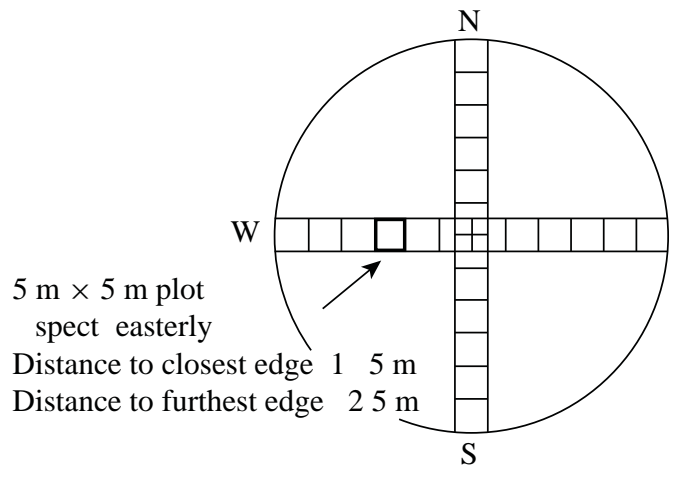

Figure 4. Schematic of sampling design, showing orientation of transects in a 60-m circular gap, and the location of $5 \mathrm{~m} \times 5 \mathrm{~m}$ plots for assessing regeneration

\section{Data analysis}

A three-stage analysis was applied to our data. The first stage involved analysis of variance (ANOVA) to identify significant differences in the mean levels of attributes describing the growth of regeneration, regardless of origin, with distance from gap edge. For this analysis, distance class was treated as a categorical variable. We analysed growth at both the tree and plot level. Tree-level growth was quantified by stem height, diameter and volume. For each growth variable the largest blackbutt tree in each $5 \mathrm{~m} \times 5 \mathrm{~m}$ plot was selected for analysis. The largest tree for each growth variable was considered a better indicator of the growth of potential crop trees than the mean of all trees in the plot. Plot-level growth was quantified by per-hectare stocking, basal area and volume of all stems within each $5 \mathrm{~m} \times 5 \mathrm{~m}$ plot. These plot-level variables were used as indicators of total productivity at a given distance from gap edge.

In the second stage of the analysis, multiple linear regression was used to model each attribute describing growth in terms of the potential explanatory variables and interactions listed in Table 6. These models were developed to better understand the range of variables that control tree growth within group-selection gaps. The models were fitted using the standard least-squares approach in a guided backward stepwise manner using JMP ${ }^{\circledR} 7.0$ statistical software. Only significant $(P<0.05)$ explanatory variables were included in the final models. Normal quantile and scatter plots of model residuals were checked for an approximately normal distribution with little heteroskedasticity.

The third and final stage addressed the effect of gap size on the composition of regeneration. The proportion of basal area and stocking attributable to intolerant, intermediate and tolerant species was estimated for each gap by summing the contribution from all $5 \mathrm{~m} \times 5 \mathrm{~m}$ plots in a gap. This provided a set of nine estimates - three for each gap size. Tests for significant differences between the means for each gap size were conducted using Student's $t$-test for the comparison of means.

\section{Results}

A total of $255,5 \mathrm{~m} \times 5 \mathrm{~m}$ plots were assessed in the nine gaps, although the geometry of the experimental design resulted in the sampling intensity of plots decreasing with distance from gap edge (Fig. 5). The 255 plots contained a total of 1200 regenerating stems ranging in age from 14.5 to $15.5 \mathrm{y}$ with a mean dbh of $11.3 \mathrm{~cm}$ (range $0.8-30.2 \mathrm{~cm}$ ) and a mean height of $11.9 \mathrm{~m}$ (range $1.7-28.4 \mathrm{~m}$ ). In terms of origin, 33\% of regeneration was from natural regeneration, 52.5\% from coppice regeneration and $14.5 \%$ from planted regeneration. Sixty-five percent (166) of the 255 plots contained at least one blackbutt stem.

\section{ANOVA testing of the effect of distance from gap edge}

\section{Tree-level growth}

We investigated the suppressive influence of gap edges on the height, diameter and volume growth of dominant blackbutt trees in the $166,5 \mathrm{~m} \times 5 \mathrm{~m}$ plots that contained at least one blackbutt tree. The largest blackbutt tree for each growth variable was selected in each of the 166 plots. ANOVA results for these data indicated significantly $(P<0.05)$ lower height, diameter and volume growth 
Table 5. Variables describing the growth and composition of regeneration in group selection gaps, and measured within each $5 \mathrm{~m} \times 5 \mathrm{~m}$ plot

\begin{tabular}{|c|c|}
\hline Variable & Method of calculation \\
\hline \multicolumn{2}{|l|}{ Growth (tree level) } \\
\hline Maximum blackbutt height & Largest blackbutt by height $(\mathrm{m})$ within a $5 \mathrm{~m} \times 5 \mathrm{~m}$ plot \\
\hline Maximum blackbutt diameter & Largest blackbutt by diameter at breast height over bark $(\mathrm{cm})$ within a $5 \mathrm{~m} \times 5 \mathrm{~m}$ plot \\
\hline Maximum blackbutt volume & Largest blackbutt by volume $\left(\mathrm{m}^{3}\right)$ within a $5 \mathrm{~m} \times 5 \mathrm{~m} \mathrm{plot}^{\mathrm{A}}$ \\
\hline \multicolumn{2}{|l|}{ Growth (plot level) } \\
\hline Plot stocking & Number of stems within a $5 \mathrm{~m} \times 5 \mathrm{~m}$ plot on a per-hectare basis \\
\hline Plot basal area & Basal area $\left(\mathrm{m}^{2}\right)$ of all stems within $5 \mathrm{~m} \times 5 \mathrm{~m}$ plot on a per-hectare basis \\
\hline Plot volume & Volume $^{\mathrm{B}}$ of all stems within a $5 \mathrm{~m} \times 5 \mathrm{~m}$ plot on a per-hectare basis \\
\hline \multicolumn{2}{|l|}{ Composition } \\
\hline Percent intolerant stocking & Percentage of $5 \mathrm{~m} \times 5 \mathrm{~m}$ plot stocking comprised of intolerant species \\
\hline Percent intermediate stocking & Percentage of $5 \mathrm{~m} \times 5 \mathrm{~m}$ plot stocking comprised of intermediate species \\
\hline Percent tolerant stocking & Percentage of $5 \mathrm{~m} \times 5 \mathrm{~m}$ plot stocking comprised of tolerant species \\
\hline Percent intolerant basal area & Percentage of $5 \mathrm{~m} \times 5 \mathrm{~m}$ plot basal area comprised of intolerant species \\
\hline Percent intermediate basal area & Percentage of $5 \mathrm{~m} \times 5 \mathrm{~m}$ plot basal area comprised of intermediate species \\
\hline Percent intolerant basal area & Percentage of $5 \mathrm{~m} \times 5 \mathrm{~m}$ plot basal area comprised of tolerant species \\
\hline
\end{tabular}

Table 6. Potential explanatory variables measured in $5 \mathrm{~m} \times 5 \mathrm{~m}$ plots and used for modelling the growth of regeneration in group selection gaps

\begin{tabular}{|c|c|}
\hline Variables $^{\mathrm{A}}$ & Range or factor levels \\
\hline Position in gap & North; South; East; West \\
\hline $\begin{array}{l}\text { Basal area }(5 \times 5 \text { m plots }) \\
\text { Total basal area } \\
\text { Percent intolerant } \\
\text { Percent intermediate } \\
\text { Percent tolerant } \\
\text { Percent tolerant }+ \text { intermediate }\end{array}$ & $\begin{array}{l}0.25-72.40 \mathrm{~m}^{2} \mathrm{ha}^{-1} \\
0-100 \% \\
0-100 \% \\
0-100 \% \\
0-100 \%\end{array}$ \\
\hline Distance to closest edge $\mathrm{e}^{\mathrm{B}, \mathrm{C}}$ & $2.5-52.5 \mathrm{~m}$ \\
\hline Distance to furthest edge & 32.5-119.3 m \\
\hline $\begin{array}{l}\text { Gap size } \\
\text { Relative gap size } \\
\text { Actual gap size }\end{array}$ & $\begin{array}{l}\text { Small; Medium; Large } \\
0.29-0.97 \text { ha }\end{array}$ \\
\hline Location & Coffs Harbour; Port Macquarie \\
\hline Origin of regeneration & $\begin{array}{l}\text { Natural regeneration (from seed and lignotuber); Coppice regeneration (resprouting from } \\
\text { stumps of harvested trees); Planted regeneration (planted nursery raised seedlings) }\end{array}$ \\
\hline $\begin{array}{l}\text { Stocking }(5 \times 5 \text { m plots }) \\
\text { Total stocking } \\
\text { Percent intolerant } \\
\text { Percent intermediate } \\
\text { Percent intolerant } \\
\text { Percent tolerant + intermediate }\end{array}$ & $\begin{array}{l}400-6800 \text { stems } \mathrm{ha}^{-1} \\
0-100 \% \\
0-100 \% \\
0-100 \% \\
0-100 \%\end{array}$ \\
\hline
\end{tabular}

$0-5 \mathrm{~m}$ from the gap edge compared with most other distance classes (Fig. 6). Outside this zone, there was a trend for growth across distance classes to remain fairly constant, indicating dominant blackbutt trees were susceptible to suppression only when close to gap edges. The increased uncertainty, or larger error bars, associated with average growth values far from gap edges (Fig. 6) reflected the fewer samples at these distances and thus greater variation in the mean calculated from these samples (Fig. 5). 


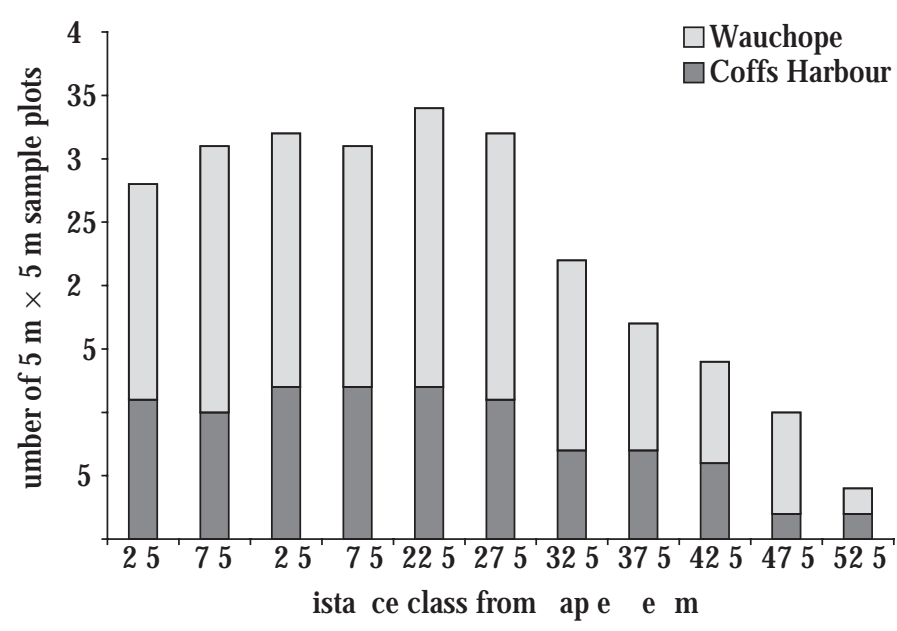

Figure 5. Distribution of $5 \mathrm{~m} \times 5 \mathrm{~m}$ sample plots across distance classes from gap edge

\section{Plot-level growth}

To investigate the suppressive influence of gap edges on total productivity, the per-hectare stocking, basal area and volume of all stems was calculated within each $5 \mathrm{~m} \times 5 \mathrm{~m}$ plot. ANOVA results indicated that apart from the 5-10 m and 10-15 m distance classes, stocking within $5 \mathrm{~m}$ of the gap edge was not significantly different from stocking at other distance classes (Fig. 7a). The significant increase in stocking between 5 and $15 \mathrm{~m}$ may reflect the surrounding forest being close enough to elevate seed supply, yet sufficiently distant to avoid inhibiting regeneration. However, we did not have data on seed supply and were unable to test this hypothesis. In contrast to stocking, plot basal area and volume within five metres from the gap edge were significantly $(P<0.05)$ lower than all other distance classes (Fig. 7b, c). These results suggest that basal area and volume were susceptible to suppression within close proximity to gap edges, while plot stocking appeared relatively unaffected.

\section{Multiple regression models of tree- and plot-level growth}

\section{Tree-level growth models}

Multiple linear regression was used to model the relationship between tree-level growth variables (Table 5) and a range of potential explanatory variables (Table 6). Intuitively, the effect of edges in any model should move towards an asymptote as distance from edge of gap increases. For this reason we fitted our regression models to the $\ln$ (distance) rather than distance on the raw scale. The following highly significant models $(P<0.01)$ were fitted for the prediction of maximum blackbutt height, diameter and volume within the $166,5 \mathrm{~m}$ $\times 5 \mathrm{~m}$ sample plots that contained at least one blackbutt tree:

blackbutt height (m)

$$
\begin{aligned}
& =16.0+0.962 \ln \left(D_{1}\right)+\text { position }_{i} \\
& + \text { origin }_{k}+0.00113 \times \text { stocking } \\
& +0.0734 \times \% S_{T+I}-0.162 \\
& \times \% \mathrm{BA}_{T+I} \quad\left(R^{2}=0.60\right),
\end{aligned}
$$

a Ma imum blackbutt height

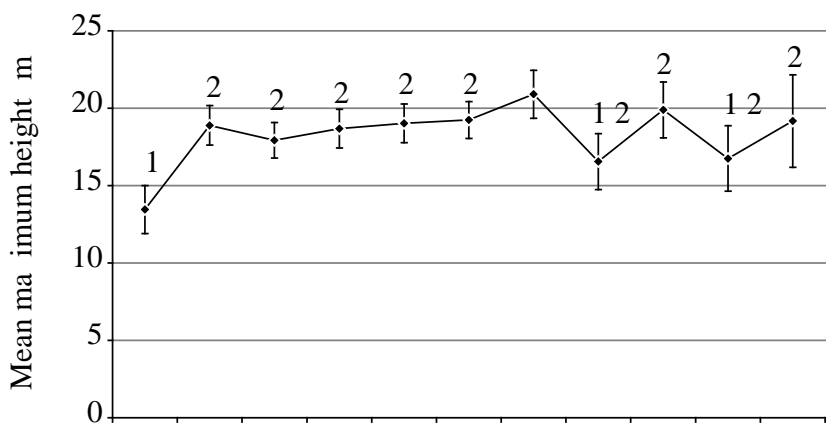

b Ma imum blackbutt diameter

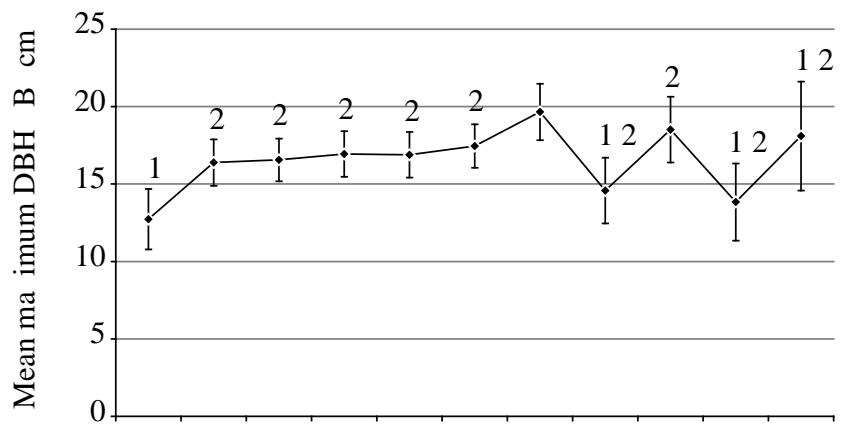

c Ma imum blackbutt olume

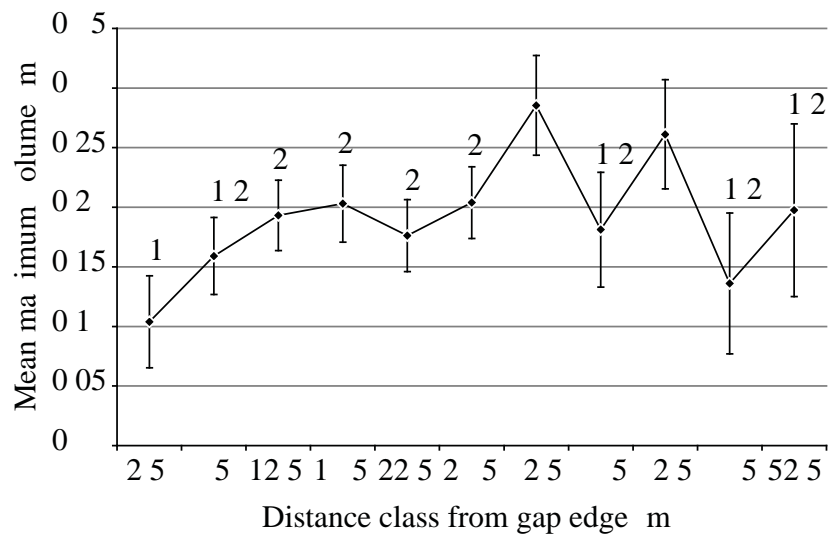

Figure 6. Trend lines and ANOVA results comparing (a) mean maximum blackbutt height, (b) mean maximum blackbutt diameter and (c) mean maximum blackbutt volume in $5 \mathrm{~m} \times 5 \mathrm{~m}$ plots, for different distance classes from gap edge. Standard errors are shown as bars. Means sharing a common superscript were not significantly different $(P>0.05)$.

blackbutt diameter $(\mathrm{cm})$

$$
\begin{aligned}
= & 12.3+1.36 \ln \left(D_{1}\right)+\text { position }_{i}+\text { location }_{j}+\text { origin }_{k} \\
& +0.00118 \times \text { stocking }+0.105 \times \% S_{T+I}-0.224 \\
& \times \% \mathrm{BA}_{T+I} \quad\left(R^{2}=0.62\right),
\end{aligned}
$$

blackbutt volume $\left(\mathrm{m}^{3}\right)$

$$
\begin{aligned}
= & 0.442+0.0343 \times \ln \left(D_{1}\right)+\text { position }_{i}+\text { location }_{j} \\
& + \text { origin }_{k}+0.0000268 \times \text { stocking }+0.00190 \\
& \times \% S_{T+I}-0.00396 \times \% \mathrm{BA}_{T+I} \quad\left(R^{2}=0.54\right),
\end{aligned}
$$

where $D_{1}$ is the distance (m) from the plot centre to the closest gap edge; 'stocking' is the number of stems in a $5 \mathrm{~m} \times 5 \mathrm{~m}$ sampling 
a Mean total plot stocking

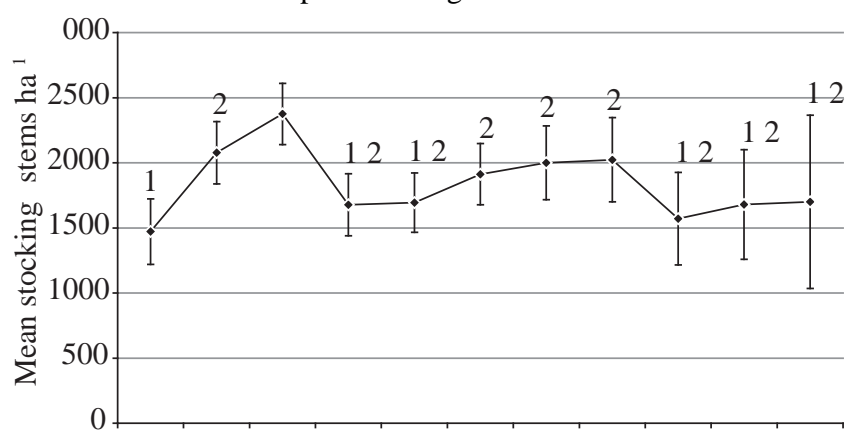

b Mean plot basal area
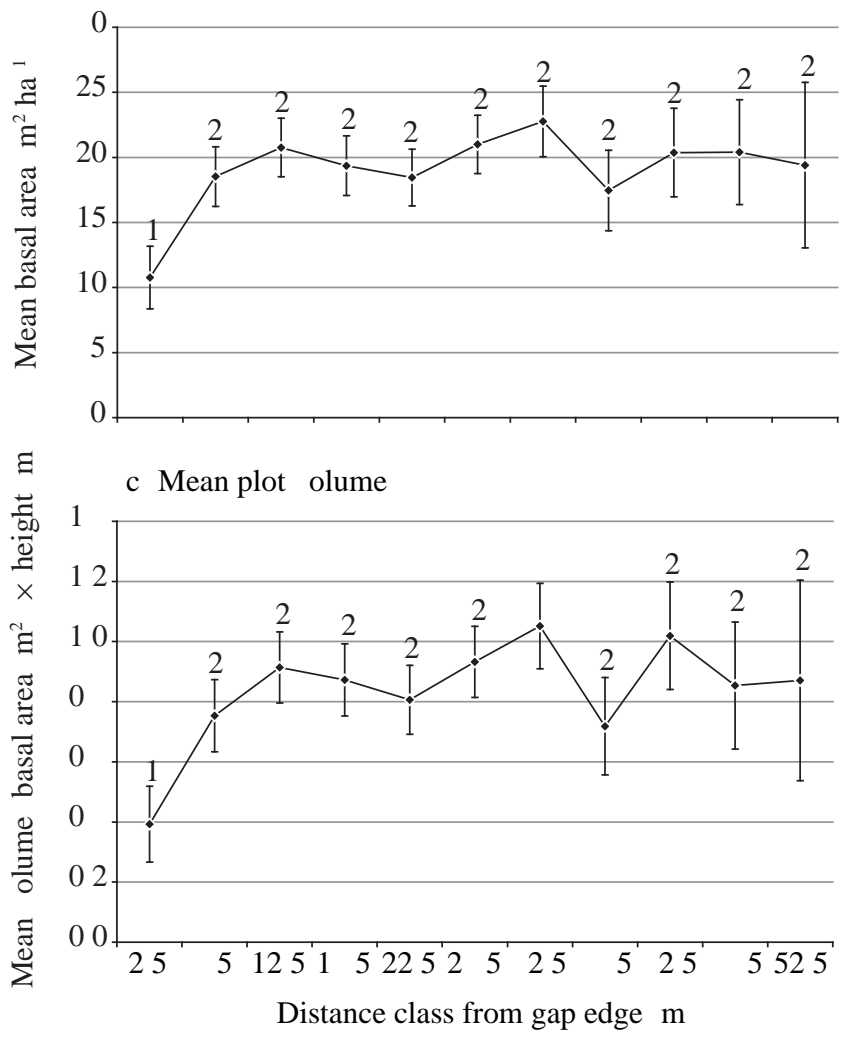

Figure 7. Trend lines and ANOVA results comparing (a) mean total stocking, (b) mean basal area and (c) mean volume in $5 \mathrm{~m} \times 5 \mathrm{~m}$ plots, for different distance classes from gap edge. Standard errors are shown as bars. Means sharing a common superscript were not significantly different $(P>0.05)$. plot expressed on a per-hectare basis; $\% S_{T+I}$ and $\% \mathrm{BA}_{T+I}$ are the percentage of the stocking and basal area within a $5 \mathrm{~m} \times 5 \mathrm{~m}$ plot comprising tolerant and intermediate species; position $_{i}$, location $_{j}$ and origin ${ }_{k}$ are factors with effects shown in Table 7. The fit of the models was good, with normal quantile and scatter plots indicating residuals were approximately normally distributed with little heteroskedasticity.

The contribution of each explanatory variable to the models (Table 8), indicated distance to gap edge explained a relatively small proportion of the variation modelled (3.7-7.0\%). Other variables (e.g. proportion of basal area comprising tolerant and intolerant species, position within gap and regeneration origin) had a greater effect on the growth of dominant blackbutt trees than distance from gap edge.

\section{Plot-level growth models}

Following the approach for tree-level growth, multiple linear regression was used to model the relationship between the plotlevel growth variables (Table 5 ) and potential explanatory variables (Table 6). The following highly significant models $(P<0.01)$ were fitted to predict the stocking ( stems ha-1), basal area $\left(\mathrm{m}^{2} \mathrm{ha}^{-1}\right)$ and volume $\left(\mathrm{m}^{3} \mathrm{ha}^{-1}\right)$ of all stems within $255,5 \mathrm{~m} \times 5 \mathrm{~m}$ sample plots: plot stocking (stems ha-1)

$$
\begin{aligned}
& =260-8.29 \times \ln \left(D_{1}\right)+\text { position }_{i} \\
& + \text { location }_{j}+63.2 \times \text { basal area } \\
& +11.7 \times \% S_{T+I} \quad\left(R^{2}=0.61\right),
\end{aligned}
$$

plot basal area $\left(\mathrm{m}^{2} \mathrm{ha}^{-1}\right)$

$$
\begin{aligned}
& =3.62+2.16 \times \ln \left(D_{1}\right)+\text { position }_{i}+\text { location }_{j} \\
& +0.00701 \times \text { stocking }-0.0922 \\
& \times \% \mathrm{BA}_{T+I} \quad\left(R^{2}=0.54\right),
\end{aligned}
$$

plot volume $\left(\mathrm{m}^{3} \mathrm{ha}^{-1}\right)$

$$
\begin{aligned}
& =0.172+0.124 \times \ln \left(D_{1}\right)+\text { position }_{i}+\text { location }_{j} \\
& +0.000277 \times \text { stocking }+0.00485 \times \% S_{T+I}-0.0107 \\
& \times \% \mathrm{BA}_{T+I} \quad\left(R^{2}=0.51\right),
\end{aligned}
$$

where $D_{1}$ is the distance to the closest edge from the plot centre (m); 'basal area' is the sum of the basal areas $\left(\mathrm{m}^{2}\right)$ of all trees within a $5 \mathrm{~m} \times 5 \mathrm{~m}$ sampling plot expressed on a per-hectare basis; 'stocking'

Table 7. Effects in multiple regression models of tree-level growth for the categorical variables 'position' (within gap), 'location' (of gap) and 'origin' (of regeneration)

\begin{tabular}{llccc}
\hline \multirow{2}{*}{ Variable } & Level & \multicolumn{3}{c}{ Effect } \\
\cline { 3 - 5 } & & Height model & Diameter model & Volume model \\
\hline \multirow{2}{*}{ position } & South & 1.24 & 1.16 & 0.0382 \\
& North & -2.40 & -2.77 & -0.0674 \\
& West & -0.330 & -0.233 & -0.0122 \\
& East & 1.50 & 1.85 & 0.0414 \\
\multirow{5}{*}{ location } & Coffs Harbour & Not an effect & -1.10 & -0.0283 \\
& Wauchope & Not an effect & 1.10 & 0.0283 \\
origin & Natural & -2.37 & -1.82 & -0.0401 \\
& Coppice & 1.91 & 0.189 & -0.00531 \\
& Planted & 0.468 & 1.68 & 0.0454 \\
\hline
\end{tabular}


Table 8. Relative contribution of significant explanatory variables in tree-level growth models

\begin{tabular}{|c|c|c|c|}
\hline \multirow[t]{2}{*}{ Variable } & \multicolumn{3}{|c|}{$\begin{array}{l}\text { Relative contribution to model } \\
\text { (\% deviance explained) }\end{array}$} \\
\hline & Height model & Diameter model & Volume model \\
\hline position $^{\mathrm{A}}$ & 14.9 & 11.0 & 17.5 \\
\hline $\ln \left(D_{1}\right)^{\mathrm{B}}$ & 3.7 & 4.3 & 7.0 \\
\hline location $_{i}{ }^{\mathrm{C}}$ & N/A & 3.3 & 5.5 \\
\hline $\operatorname{origin}_{i}{ }^{\mathrm{D}}$ & 8.0 & 5.9 & 8.6 \\
\hline stocking $^{\mathrm{E}}$ & 9.3 & 5.1 & 6.6 \\
\hline$\% \mathrm{BA}_{T+I} \mathrm{~F}$ & 55.2 & 60.0 & 46.4 \\
\hline$\% S_{T+I}^{G}$ & 8.9 & 10.3 & 8.4 \\
\hline $\begin{array}{l}\text { Factor with } 1 \\
\text { Natural loga } \\
\text { Factor with I } \\
\text { Factor with I } \\
\text { Number of s } \\
\text { Percentage o } \\
\text { Percentage o }\end{array}$ & $\begin{array}{l}\text { st or west } \\
\text { he nearest gap ed } \\
\text { or Wauchope } \\
\text { g or coppice } \\
\mathrm{m} \text { expressed on } \\
\mathrm{d} \text { of tolerant and } \\
\text { of tolerant and ir }\end{array}$ & $\begin{array}{l}\text { ctare basis } \\
\text { diate species } \\
\text { iate species }\end{array}$ & \\
\hline
\end{tabular}

is the number of stems in a $5 \mathrm{~m} \times 5 \mathrm{~m}$ sampling plot expressed on a per-hectare basis; $\% S_{T+I}$ and $\% \mathrm{BA}_{T+I}$ are the percentage of the stocking and basal area within a $5 \mathrm{~m} \times 5 \mathrm{~m}$ plot, comprised of tolerant and intermediate species; position $_{i}$ and location ${ }_{j}$ are factors with effects shown in Table 9. The fit of the models was good, with normal quantile and scatter plots indicating the residuals were approximately normally distributed with little heteroskedasticity.

In a result similar to the tree-level models, distance to gap edge explained a relatively small proportion of plot-level variation, with other variables (basal area, stocking, position within gap and location) having a greater effect on plot-level growth (Table 10).

\section{The effect of gap size on the composition of regeneration}

Although there were weak trends in which the proportion of gap occupied by intolerant species increased with gap size, the proportion of tolerant species decreased with gap size, and intermediate species showed a weak association with medium size gaps; none of these trends were significant.

\section{Discussion}

\section{Growth modelling}

Our ANOVA results indicate tree height, diameter, volume and basal area were significantly reduced within $5 \mathrm{~m}$ of gap edges. Beyond this zone growth remained fairly constant. These results are comparable with those of Henry and Florence (1966), who found that the growth of lignotuberous seedlings in Corymbia maculata ((Hook.) K.D.Hill \& L.A.S.Johnson) - E. drepanophylla (F.Muell. ex Benth.) forest was suppressed for about $15 \mathrm{~m}$ from the edge of a clearfell coupe. The larger zone of reduced growth may in part reflect lower soil moisture and nutrient levels in the dry forest they studied compared with mixed-species blackbutt forest. This is supported by Opie (1968), who found the zone of influence for E. camaldulensis (Denh.) trees increased as site quality decreased. Large zones of influence, however, can also be associated with high-quality sites occupied by very shadeintolerant species such as E. regnans (F.Muell.) (Basset and White 2000; Van der Meer and Dignan 2007); although Van der Velden (2009) found the growth of 20-y-old E. regnans stands regenerated following clearfelling was significantly reduced for only 0-10 m from retained forest edges, despite attenuated light levels extending $60 \mathrm{~m}$ into the coupes.

Our assessment of forest adjacent to gaps indicated the average diameter of dominant trees in gap edges was about $80 \mathrm{~cm}$. According to Mackowski (1984), an 80-cm blackbutt tree should have a crown radius of about $8.5 \mathrm{~m}$, so that the $5 \mathrm{~m}$ 'zone of influence' we observed would extend $13.5 \mathrm{~m}$, or 1.6 crown radii, from the stem of dominant trees at the edge of gaps. This result is close to the zone of influence of 1.7-1.8 crown radii reported for E. fastigata (H.Deane \& Maiden) by Bi and Jurskis (1997) but smaller than zones of influence between 1.8 and 2.8 crown radii reported for E. camaldulensis (Denh.) by Opie (1968),

Table 9. Effects in multiple regression models of plot-level growth for the categorical variables 'position' (within gap) and 'location' (of gap)

\begin{tabular}{llccc}
\hline \multirow{2}{*}{ Variable } & Level & \multicolumn{3}{c}{ Effect } \\
\cline { 3 - 5 } & & Stocking model & Basal area model & Volume model \\
\hline \multirow{2}{*}{ position } & South & -286 & 3.16 & 0.160 \\
& North & 390 & -4.90 & -0.253 \\
& West & 63 & -1.09 & -0.0815 \\
& East & -167 & 2.83 & 0.174 \\
\multirow{7}{*}{ location } & Coffs Harbour & 518 & -3.29 & -0.152 \\
& Wauchope & -518 & 3.29 & 0.152 \\
\hline
\end{tabular}


Table 10. Relative contribution of significant explanatory variables in plot-level growth models

\begin{tabular}{|c|c|c|c|}
\hline \multirow[t]{2}{*}{ Variable } & \multicolumn{3}{|c|}{$\begin{array}{l}\text { Relative contribution to model } \\
\text { (\% deviance explained) }\end{array}$} \\
\hline & Stocking model & Basal area model & Volume model \\
\hline position $^{\mathrm{A}}$ & 5.7 & 10.3 & 16.7 \\
\hline basal area ${ }^{\mathrm{B}}$ & 56.2 & N/A & N/A \\
\hline $\ln \left(D_{1}\right)^{\mathrm{C}}$ & 1.1 & 3.2 & 6.0 \\
\hline location $_{i}{ }^{\mathrm{D}}$ & 22.4 & 7.6 & 9.1 \\
\hline stocking $^{\mathrm{E}}$ & N/A & 11.6 & 17.3 \\
\hline$\% \mathrm{BA}_{T+I}^{\mathrm{F}}$ & 14.6 & N/A & 2.6 \\
\hline$\% S_{T+I}^{\mathrm{G}}$ & 5.7 & 10.3 & 16.7 \\
\hline $\begin{array}{l}{ }^{\mathrm{A}} \text { Factor with lev } \\
{ }^{\mathrm{B}} \text { Basal area of a } \\
{ }^{\mathrm{C}} \text { Distance to the } \\
{ }^{\mathrm{D}} \text { Factor with le } \\
{ }^{\mathrm{E}} \text { Number of ster } \\
{ }^{\mathrm{E}} \text { Percentage of } \\
{ }^{\mathrm{G}} \text { Percentage of }\end{array}$ & $\begin{array}{l}\text { east or west } \\
5 \mathrm{~m} \times 5 \mathrm{~m} \text { plot on a } \\
(\mathrm{m}) \\
\text { our or Wauchope } \\
5 \mathrm{~m} \text { plot expressed } \\
\text { ed of tolerant and in } \\
\mathrm{d} \text { of tolerant and int }\end{array}$ & $\begin{array}{l}\text { er-hectare basis } \\
\text { diate species } \\
\text { liate species }\end{array}$ & \\
\hline
\end{tabular}

for Eucalyptus diversicolor (F.Muell.) by Rotheram (1983), for E. tricarpa ((L.A.S.Johnson) L.A.S.Johnson \& K.D.Hill) by Kellas et al. (1996, cited in Basset and White 2000), and for E. molucanna (Roxb.), E. tereticornis (Smith), E. tindaliae (Blakely), Angophora subvelutina (F.Muell.) and Lophostemon suaveolans (Sol. ex Gaertner) by Bi et al. (2002). In contrast to these studies Incoll (1979) reported a 'zone of influence' of about 6 crown radii from retained E. sieberi (L.A.S.Johnson) trees. However, like Henry and Florence (1966), Incoll's (1979) study was in a dry forest type, which may account for the markedly larger 'zone of influence'. Bassett and White (2000) also suggest Incoll may have overestimated the zone of influence by selecting trees with healthy full crowns rather than using a random sample of trees displaying a range of crown conditions representative of natural stands.

Our multiple regression models confirmed the relatively short distance from gap edges over which suppression occurred, with distance to closest gap edge explaining a small proportion of the variation in the models fitted for tree- and plot-level growth. In addition to distance to the closest edge, position within gap, origin of regeneration, location, stocking, and the proportion of stocking and basal area comprising tolerant and intermediate species, were significant explanatory variables. Unlike previous studies by Van der Meer et al. (1999) and Van der Meer and Dignan (2007), gap size was not significant in any of our regression models, which suggests that the variation within gaps was greater than the variation between gaps. However, if a wider range of gap sizes were assessed it is possible that the variation between gaps would have become significant.

The effect of position within gap in the multivariate models indicated that areas with a northerly or westerly aspect (i.e. the southern and eastern parts of the gaps) produce the greatest growth by blackbutt regeneration. This suggests blackbutt growth is positively correlated with solar radiation. A similar trend was identified for E. delegatensis (R.T.Baker) by Bowman and Kirkpatrick (1986), who identified a significant relationship between solar radiation and sapling diameter, height and wet weight. Although our results support the classification of blackbutt as a shade-intolerant species (Jacobs 1955; Florence 1996), the relatively small zone of influence of 1.6 crown radii we observed suggests it may be less shade intolerant than previously thought.

Unlike previous studies that have investigated growth within group selection gaps (Van der Meer et al. 1999; Van der Meer and Dignan 2007; Van der Velden 2009), we included the effects of competition between regenerating stems in our regression analysis. Our fitted models indicated total stocking and proportion of stocking attributable to tolerant and intermediate species had a positive influence on the growth of blackbutt regeneration. This is potentially related to a higher stocking stimulating early growth and differentiation, and an increased proportion of tolerant and intermediate species resulting in less competition between intolerant species such as blackbutt. In contrast, the proportion of basal area, comprising tolerant and intermediate species, had a strong negative affect on blackbutt growth. Therefore, a high proportion of stocking attributable to tolerant and intermediate species appears favourable for the growth of blackbutt, providing it occupies a small proportion of available growing space.

The origin of blackbutt regeneration within gaps was a significant effect in tree-level growth models, with planted regeneration having increased diameter and volume growth compared with natural regeneration. This superior growth probably reflects the fact that seedlings are approximately a year old when planted, and have been raised under ideal growing conditions. The seed used to propagate the seedlings may have also been collected from phenotypically superior trees. No other studies have compared the growth of planted, natural and coppice regeneration in group selection gaps. This is probably because enrichment planting is seen as one means of achieving adequate stocking of desired species after harvesting (Jurskis 2000; CALM 2004), rather than a means of improving forest growth.

\section{Composition of gaps}

We found there were no significant differences in the proportion of basal area or stocking attributable to intolerant, intermediate or tolerant species between the three gap sizes tested (Fig. 8). This result contrasts with published ecological theory concerning forest gaps (Oliver and Larson 1996; Smith et al. 1996; Howe 1990) and 
a Intolerant species

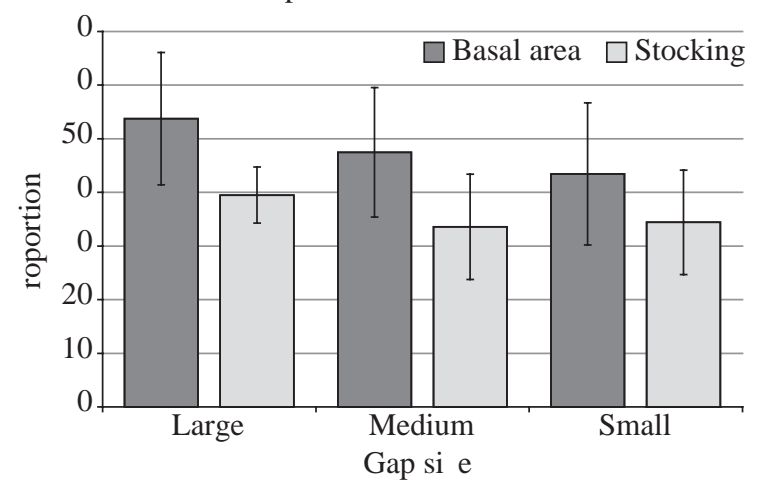

b Intermediate species

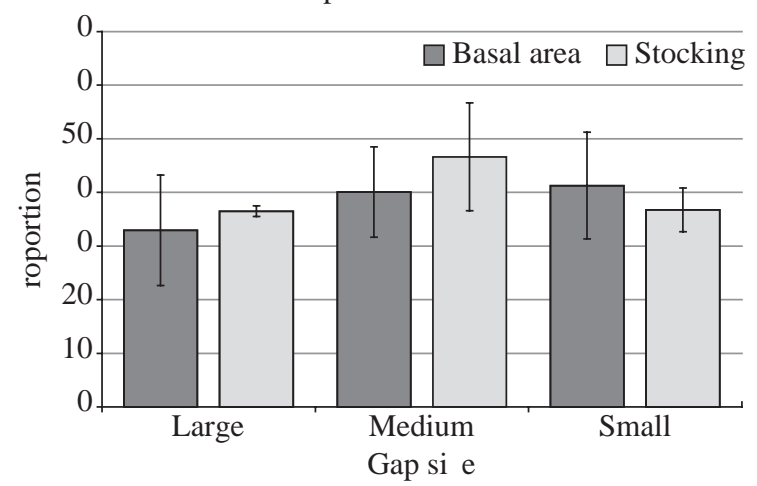

c Tolerant species

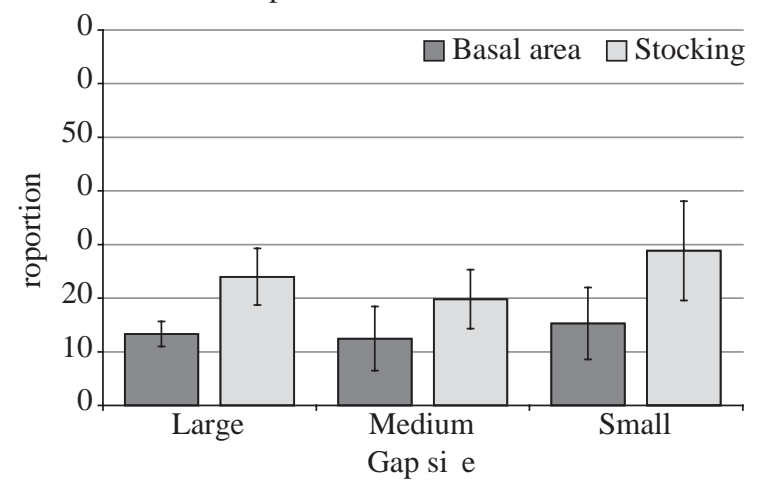

Figure 8. The mean proportion of basal area and stocking attributable to (a) intolerant, (b) intermediate and (c) tolerant trees across the three gap sizes (large $0.93-0.97 \mathrm{ha}$; medium $0.45-0.67 \mathrm{ha}$; small $0.27-0.3 \mathrm{ha}$ ). No means were significantly different $(P>0.05)$. Standard errors are shown as bars.

observations in tropical and northern hemisphere coniferous and mixed hardwood forests (Denslow 1980; Brokaw and Scheiner 1989; Canham 1989; Poulson and Platt 1989; Murphy et al. 1993; Lamson and Leak 2000) in which the proportion of space suitable for intolerant species increases with gap size. This suggests that the relative difference between tolerant and intolerant species in mixed-species blackbutt forests may be less than in other forests subjected to uneven-aged silviculture. Consequently, a wider range of gap sizes than was sampled in this study may be needed to identify differences in composition due to gap size. We were also limited to three replicates for each gap size and so the consequent uncertainty in our means may have masked significant differences due to gap size.

\section{Management implications}

Our results suggest a number of management actions concerning gap size, thinning, gap location and establishment that may improve the productivity of mixed-species blackbutt forest.

\section{Gap size}

We identified a zone of significantly reduced growth within $5 \mathrm{~m}$ of gap edges. Consequently the proportion of gap area where growth is unrestricted will increase with gap size (Fig. 9). For example, in a gap of 0.25 ha-which is the current maximum gap size for state forest in NE NSW-68\% of the gap area is within the zone of unrestricted growth, compared with $85 \%$ in a 1-ha gap. Our results also demonstrate that gaps within the range of sizes tested (0.27-0.97 ha) are unlikely to change the species composition of mixed-species blackbutt forest. Given the high priority of sustainable timber production within large tracts of state forest in NSW (State Forests of NSW 1999), our results indicate the use of a 1-ha gap would improve growth compared with smaller gaps, without compromising the composition of regeneration. A 1-ha gap also has operational advantages compared with smaller gaps, such as safer and easier harvesting, reduced damage to the surrounding forest, fewer and more easily controlled regeneration burns, and reduced roading costs (Bradshaw 1992). For example, Mitchell (1997) found the frequency of injuries to forestry workers decreased with increasing gap size in mountain ash forest, and concluded that only gaps greater than 0.5 ha in area could achieve acceptable levels of safety. King (1997) found the cost of site preparation treatments involving mechanical soil disturbance or burning increased substantially as harvest area decreased, with the per-hectare cost of treating small gaps ( $0.25 \mathrm{ha})$ almost twice that of large gaps (2 ha). In a simulation study, Burgess (1997) found large gaps (1-2 ha) required 30\% less roading infrastructure than small gaps ( $<1 \mathrm{ha}$ ) for an equivalent net harvestable area.

Despite growth and operational advantages, 1-ha gaps may exceed the distance of natural seed-throw from edge trees. The usual rule of thumb in eucalypt forests is that effective seed dispersal distance

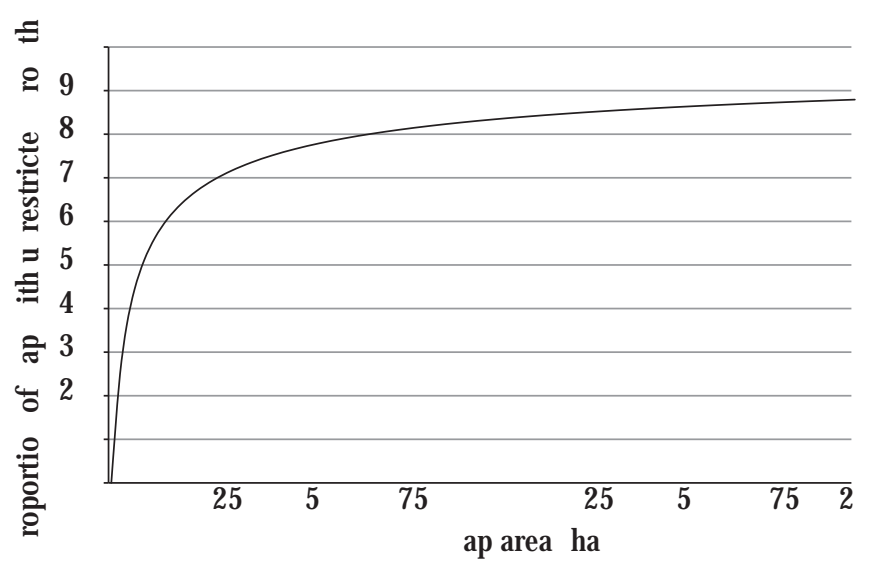

Figure 9. The proportion of a circular group-selection gap with unrestricted growth, for a range of gap sizes and a zone of restricted growth extending $5 \mathrm{~m}$ from gap edges 
is about equal to the height of the parent tree (Jacobs 1955; Cremer 1977; Eldridge et al. 1993). The mean stand height of trees adjacent to our gaps was $39.5 \mathrm{~m}$ at Coffs Harbour and $43.4 \mathrm{~m}$ at Wauchope, distances less than the 56-m radius of a 1-ha circular gap. Although a number of studies have attempted to quantify the seed dispersal distance for blackbutt, there is little consensus in their findings. In a 1962 study, Floyd estimated the effective establishment distance as no more than $10 \mathrm{~m}$ from a mature blackbutt, but in a 1969 study he found effective regeneration $90 \mathrm{~m}$ from an isolated parent tree (Baur 1983). In a laboratory study, Cremer (1977) estimated a seed-throw distance of $21.1 \mathrm{~m}$ for blackbutt seed falling from a $40-\mathrm{m}$ tree with $10 \mathrm{~km} \mathrm{~h}^{-1}$ wind. Given the uncertainty associated with seed dispersal distances, enrichment plantings or artificial sowing would be needed for gaps with diameters exceeding twice the stand height. For forests of the stature we studied, this equates to circular gaps exceeding 0.5 ha in area.

\section{Thinning and location of gaps}

Position within gap was a significant effect in our regression models predicting stem growth, with reduced growth for parts of the gap with southerly and easterly aspects. This result suggests thinning the forest surrounding the northern and western side of gaps could be used to stimulate growth by increasing light penetration into the most shaded parts of gaps. Alternatively, subsequent gaps could be located on the northern or western side of established gaps. Increased light penetration could also be achieved by modifying gap geometry, although any deviation from a circular design will increase the proportion of the gap in the zone of reduced growth caused by edge trees. The results of the tree-level growth models also suggest that thinning of tolerant and intermediate species within the gaps may stimulate growth of individual blackbutt trees. More research is required, however, to determine the optimum timing of such operations.

\section{Establishment of regeneration in gaps}

The tree-level growth models suggest that high initial stocking stimulates early growth of blackbutt. It is therefore important to ensure adequate site preparation is undertaken to create a seed bed suitable for maximising the establishment of regeneration. Given the comparative advantage of planted regeneration, we also recommend that gaps are enrichment-planted with blackbutt seedlings propagated from local seed sources.

\section{Acknowledgements}

We are grateful for support from Piers Harper, Darrel Johnstone, Bob Dean, Jim O’Hara, Dan Cook, John Murray, David Wilson, Steve Boyton and Tim Parkes of Forests NSW. Matthew Kinny was supported by an ACTION Trust Honours Scholarship. Comments by two anonymous referees and the panel editor improved the manuscript.

\section{References}

Auditor General (2009) Sustaining Native Forest Operations: Forests NSW. The Audit Office of New South Wales, Sydney, 54 pp.

Bassett, O.D. and White, G. (2000) Review of the impact of retained overwood trees on stand productivity. Australian Forestry 64, 57-63.

Baur, G.N. (1983) Notes on the Silviculture of Major NSW Forest Types - 4. Blackbutt Types. Forestry Commission of NSW, Sydney, $60 \mathrm{pp}$.

Bi, H., Bruskin, S. and Smith, R.G.B. (2002) The zone of influence of paddock trees and the consequent loss in volume in young Eucalyptus dunnii plantations. Forest Ecology and Management 165, 305-315.

Bi, H. and Hamilton, F. (1998) Stem volume equations for native tree species in southern New South Wales and Victoria. Australian Forestry 61, 275-286.

Bi, H. and Jurskis, V. (1997) Crown radius and zone of influence of oldgrowth trees in regrowth eucalypt forests. Paper presented to Research Working Group 4 (Native Forest Silviculture). Hobart, 11-13 March 1997.

Boland, D.J., Brooker, M.I.H., Chippendale, G.M., Hall, N., Hyland, B.P.M, Johnson, R.D, Kleinig, D.A., McDonald, M.W. and Turner, J.D. (2006) Forest Trees of Australia. 5th edn. CSIRO Publishing, Collingwood, $736 \mathrm{pp}$.

Bowman, D.M.J.S. and Kirkpatrick, J.B. (1986) Establishment, suppression and growth of Eucalyptus delegatensis R.T.Baker in multiaged forests. II Sapling growth and its environmental correlates. Australian Journal of Botany 34, 73-80.

Bradshaw, F.J. (1992) Quantifying edge effect and patch size for multiple-use silviculture-a discussion paper. Forest Ecology and Management 48, 249-264.

Brokaw, N.V. and Scheiner, S.M. (1989) Species composition in gaps and structure of a tropical forest. Ecology 70, 538-541.

Bruskin, S. (1996) Blackbutt gap regeneration study. Unpublished report. Research Division, State Forests of NSW, Coffs Harbour, 15 pp.

Burgess, J. (1997) Roading operations. In: Campbell, R. (ed.) Evaluation and Development of Sustainable Silvicultural Systems for Mountain Ash Forests. Centre for Forest Tree Technology, Department of Natural Resources and Environment, Victoria, pp. 179-187.

CALM (Department of Conservation and Land Management) (2004) Silvicultural Practice in the Jarrah Forest. Sustainable Forest Management Series. SFM Guideline No. 1. Department of Conservation and Land Management, Kensington, 46 pp.

CALM (Department of Conservation and Land Management) (2005) Silvicultural Practice in the Karri Forest. Sustainable Forest Management Series. SFM Guideline No. 3. Department of Conservation and Land Management, Kensington, 31 pp.

Canham, C.D. (1989). Different responses to gaps among shade-tolerant tree species. Ecology 70, 548-550.

Chambers, D.P. and Attiwill, P.M. (1994) The ash-bed effect in Eucalyptus regnans forest: chemical, physical and microbiological changes in soil after heating or partial sterilisation. Australian Journal of Botany 42, 739-749.

Cremer, K.W. (1977) Distance of seed dispersal in eucalypts estimated from seed weights. Australian Forest Research 7, 225-228.

Curtin, R.A. and King, G.C. (1979) Blackbutt advanced regeneration: its persistence and significance. Australian Forestry 42, 161-167. 
DECC (Department of Environment and Climate Change) (2008) Private Native Forestry Code of Practice for Northern NSW. NSW Government, Sydney, 49 pp.

Denslow, J.S. (1980) Gap partitioning among tropical rainforest trees. Biotropica 12, 47-59.

DSE (Department of Sustainability and Environment) (2007) Code of Practice for Timber Production. Victorian Government, Melbourne, 86 pp.

Eldridge, K.G., Davidson, J., Hardwood, C.E. and VanWyk, G. (1993) Eucalypt Domestication and Breeding. Clarendon Press, Oxford, 288 pp.

Fairbairn, W.A. (1963) Some observations on group regeneration. Forestry 36, 113-123.

Florence, R.G. (1996) Ecology and Silviculture of Eucalypt Forests. CSIRO Publishing, Collingwood, $413 \mathrm{pp}$.

Floyd, A.G. (1962) Investigations into the Natural Regeneration of Blackbutt-E. pilularis. Research Note No. 10. Forestry Commission of New South Wales, Sydney, 32 pp.

Forest Practices Board (2000) Forest Practices Code. Tasmanian Government, Hobart, 120 pp.

Forestry Commission of NSW (1982) Management Plan for Kendall Management Area. Forestry Commission of NSW, Sydney, $92 \mathrm{pp}$.

Forestry Commission of NSW (1989) Forest Types in New South Wales. Research Note 17. Forestry Commission of NSW, Sydney, 95 pp.

Hawley, R.C. (1949) The Practice of Silviculture. John Wiley, London, 354 pp.

Henry, N.B. and Florence, R.G. (1966) Establishment and development of regeneration in spotted gum - ironbark forests. Australian Forestry 30, 304-316.

Horne, R. (1993) Gaps and Clusters: Maintaining Ecological Values and Future Wood Yield in Mature Eucalypt Forest. Silvicultural Bulletin No. 10. State Forests of New South Wales, Sydney, 11 pp.

Horne, R., Watts, G. and Robinson, G. (1991) Current forms and extent of retention areas within a selectively logged blackbutt forest in NSW: a case study. Australian Forestry 54, 148-153.

Howe, H.F. (1990) Habitat implications of gap geometry in tropical forests. Oikos 59, 141-144.

Incoll, W.D. (1979) Effect of overwood trees on growth of young stands of Eucalyptus sieberi. Australian Forestry 42, 110-116.

Jacobs, M.R. (1955) Growth Habits of the Eucalypts. Forestry and Timber Bureau, Canberra, 262 pp.

Jurskis, V. (2000) Ecologically Sustainable Forest Management: Native Forest Silvicultural Manual. State Forests of New South Wales, Pennant Hills, NSW, 46 pp.

King, M. (1997) Regeneration operations. In: Campbell, R. (ed.) Evaluation and Development of Sustainable Silvicultural Systems for Mountain Ash Forests. Centre for Forest Tree Technology, Department of Natural Resources and Environment, Victoria, pp. 199-209.

Lamson, N.I. and Leak, W.B. (2000) Guidelines for Applying Group Selection Harvesting. General Technical Report NA-TP-02-00. US Department of Agriculture, Forest Service, Northeastern Research Station, Newtown Square, 6 pp.

Mackowski, C.M. (1984) The ontogeny of hollows in blackbutt (Eucalyptus pilularis) and its relevance to the management of forests for possums, gliders and timber. In: Smith, A.P. and Hume, I.D. (eds) Possums and Gliders. Australian Mammal Society, Sydney, pp. 553-567.
McCarthy, J. (2001) Gap dynamics of forest trees: a review with particular attention to boreal forests. Environmental Reviews 9, 1-59.

Mitchell, K. (1997) Operational health and safety. In: Campbell, R. (ed.) Evaluation and Development of Sustainable Silvicultural Systems for Mountain Ash Forests. Centre for Forest Tree Technology, Department of Natural Resources and Environment, Victoria, pp. 158-169.

Murphy, P.A., Shelton, M.G. and Graney, D.L. (1993) Group selectionproblems and possibilities for the more shade-intolerant species. In: Gillespie, A.R., Parker, G.R., Pope, P.E. and Rink, G. (eds) Proceedings of the 9th Central Hardwood Forest Conference, 1993 March 8-10, West Lafayette. US Department of Agriculture, Forest Service, North Central Forest Experiment Station, pp. 229-247.

NSW Government (1999a) Integrated forestry operations approval for Lower North East Region. Resource and Conservation Unit, NSW Premier's Department. Available from: http://www.racac.nsw.gov. au/rfa/pdf/Lower_North_East_IFOA.pdf (accessed 6 October 2007)

NSW Government (1999b) Integrated forestry operations approval for Upper North East Region. Resource and Conservation Unit, NSW Premier's Department. Available from: http://www.racac.nsw. gov.au/rfa/pdf/Upper_North_East_IFOA.pdf (accessed 6 October 2007)

NSW Government (2002) Integrated forestry operations approval for Southern Region. Resource and Conservation Unit, NSW Premier's Department. Available from: http://www.racac.nsw.gov.au/rfa/pdf/ Sthrn_IFOA.pdf (accessed 6 October 2007)

Oliver, C.D. and Larson, B.C. (1996) Forest Stand Dynamics. John Wiley and Sons, New York, 520 pp.

Opie, J.E. (1968) Predictability of individual tree growth using various definitions of competing basal area. Forest Science 14, 314-323.

Ovington, J.D. and Thistlethwaite, R.J. (1976) The woodchip industry: environmental effects of cutting and regeneration practices. Search 7, 383-392.

Poulson, T.L. and Platt, W.J. (1989) Gap light regimes influence canopy tree diversity. Ecology 70, 553-555.

Rotheram, I. (1983) Suppression of growth of surrounding regeneration by veteran trees of karri (Eucalyptus diversicolor). Australian Forestry 46, 8-13.

Smith, D.M., Larson, B.C., Kelty, M.C. and Ashton, P.M.S. (1996) The Practice of Silviculture: Applied Forest Ecology. 9th edn. John Wiley and Sons, New York, 537 pp.

State Forests of NSW (1999) Managing our Forests Sustainably: Forest Management Zoning in NSW State Forests. State Forests of NSW, Sydney, 29 pp.

Van der Meer, P.J. and Dignan, P. (2007) Regeneration after eight years in artificial canopy gaps in mountain ash (Eucalyptus regnans F.Muell.) forest in south-eastern Australia. Forest Ecology and Management 244, 102-111.

Van der Meer, P.J., Dignan, P. and Saveneh, A.G. (1999) Effect of gap size on seedling establishment, growth and survival at three years in mountain ash (Eucalyptus regnans F.Muell.) forest in Victoria, Australia. Forest Ecology and Management 117, 33-42.

Van der Velden, N.T. (2009) Light, growth and edges in Eucalyptus regnans forest, Victoria, Australia. Post-graduate report. Van Hall Larenstein Forest and Nature Management, and the School of Forest and Ecosystem Science, University of Melbourne, Australia, 97 pp. 